\title{
Effect of monensin on recovery from diet-induced milk fat depression
}

\author{
D. E. Rico, ${ }^{*}$ A. W. Holloway, $†$ and K. J. Harvatine ${ }^{\star 1}$ \\ *Department of Animal Science, Penn State University, University Park 16802 \\ †Elanco Animal Health, 2500 Innovation Way, Greenfield, IN 46140
}

\section{ABSTRACT}

The objective of the present experiment was to investigate the effect of monensin (MN) on the time course of recovery from diet-induced milk fat depression. Milk fat depression was induced in all cows $(\mathrm{n}=16)$ during the first phase of each period by feeding a low-fiber, high-unsaturated fat diet $[25.3 \%$ neutral detergent fiber (NDF), $6.9 \%$ fatty acids (FA), and $3.24 \%$ C18:2] with MN (450 mg/cow per day) for 10 to $14 \mathrm{~d}$. A recovery phase of $18 \mathrm{~d}$ followed, where cows were switched to a higher-fiber and lower unsaturated fat diet $(31.2 \%$ NDF, $4.3 \% \mathrm{FA}$, and 1.7\% C18:2). According to a crossover design, treatments during recovery were (1) control (no MN supplementation) or (2) continued MN supplementation. Milk yield, milk composition, and milk FA profile were measured every $3 \mathrm{~d}$ during recovery. No effect was observed of MN on dry matter intake or yield of milk, milk protein, and lactose. Milk fat concentration and yield increased progressively during recovery in both treatments. Monensin decreased milk fat yield from d 6 to 15, but it was the same as the control on d 18. A treatment by time interaction on milk fat concentration was detected, which was decreased by MN only on $\mathrm{d} 3$ and 6 . The yield of milk de novo synthesized FA increased progressively in both treatments and was not affected by treatment. Similarly, yield of 16-C FA increased progressively, but was decreased by $\mathrm{MN}$ on d 6 and 9. Preformed FA yield was lower in the MN group from d 6 to 15, but was not different from the control on d 18. Importantly, milk FA concentration of trans-10 C18:1 and trans-10,cis-12 conjugated linoleic acid rapidly decreased in both groups; however, $\mathrm{MN}$ slightly increased trans-10 C18:1 concentration above baseline on d 15 and 18. In conclusion, MN supplementation had minimal effect on recovery of normal rumen biohydrogenation and de novo FA synthesis during recovery from milk fat depression by correction of dietary starch, NDF, and polyunsaturated FA concentration, but moderately decreased recovery of preformed FA in milk.

Received September 13, 2013.

Accepted December 19, 2013.

${ }^{1}$ Corresponding author: kjh182@psu.edu
Key words: monensin, milk fat depression, dairy cow, conjugated linoleic acid

\section{INTRODUCTION}

Milk fat depression (MFD) is characterized by a specific reduction in milk fat synthesis, and is caused by bioactive trans FA arising from altered ruminal fermentation (Bauman and Griinari, 2001). Many dietary factors affect the formation and ruminal outflow of bioactive FA, including feeding methods, dietary concentration of highly fermentable feeds, PUFA, effective fiber, and ionophores. The interaction of these risk factors sometimes results in modification of the rumen environment, the microbial population, and the pathways of FA biohydrogenation (BH), which leads to increased formation of the bioactive FA that cause MFD (Jenkins et al., 2003; Weimer et al., 2010).

Ionophores are lipophilic molecules toxic to many bacteria, protozoa, and fungi (Russell and Strobel, 1989). Monensin (MN) is an ionophore that has been shown to increase milk yield and feed efficiency in lactating dairy cows (Ipharraguerre and Clark, 2003; Duffield et al., 2008b). Monensin alters the ion flux and ATPase systems of sensitive bacteria, resulting in an increase in maintenance energy expenditure and compromised growth (Ipharraguerre and Clark, 2003). Thus, MN supplementation results in selection of ruminal bacteria that produce less $\mathrm{H}_{2}$ and acetate and more propionate and ATP (Russell and Strobel, 1989). In addition, under some circumstances, MN leads to reduced BH capacity and utilization of alternate pathways, resulting in bioactive FA formation (Fellner et al., 1997; Jenkins et al., 2003).

The effect of MN on milk fat yield and concentration is not consistent across studies, as some have reported reductions (Phipps et al., 2000; Odongo et al., 2007; AlZahal et al., 2008), whereas others have reported no effect (Lean et al., 1994; Duffield et al., 1999; He et al., 2012). It is likely that the variation in response to MN feeding is related to interactions with diet type. For example, starch source and level of dietary PUFA have been previously shown to reduce the rates of FA BH (Fellner et al., 1997; Duffield et al., 2008b) and increase the concentration of alternate $\mathrm{BH}$ intermediates, such 
as trans-10 C18:1, in rumen fluid and milk fat (Jenkins et al., 2003; AlZahal et al., 2008; He et al., 2012). In addition, MN and PUFA synergistically increased trans-10 C18:1 formation in vitro (Jenkins et al., 2003) and in vivo (AlZahal et al., 2008; He et al., 2012).

Strategies to rescue milk fat synthesis after MFD has occurred are important to reduce the duration of the condition. We have previously validated a model of MFD induction and recovery, which provided the basis for the experimental design of the current experiment (Rico and Harvatine, 2013). Briefly, during induction of MFD, milk fat yield was near the nadir by d 11 and during recovery, a higher-fiber and low-PUFA diet completely rescued milk fat yield by d 19. Previous investigations of MN have predominantly focused on the long-term or steady-state effects of supplementation; however, long-term changes in the microbial population after termination of $\mathrm{MN}$ have been reported (Weimer et al., 2008). The objective of the current study was to investigate the effect of MN on the rate of recovery of milk fat synthesis and milk FA profile after induction of MFD while supplementing MN in dairy cows. The hypothesis was that MN would minimally affect the rate of recovery of milk fat synthesis.

\section{MATERIALS AND METHODS}

\section{Experimental Design and Treatments}

The experiment was conducted from February to May of 2012. All experimental procedures were approved by the Pennsylvania State University Institutional Animal Care and Use Committee (University Park). Sixteen multiparous Holstein cows $(183 \pm 21$ d postpartum; mean $\pm \mathrm{SD}$ ) were randomly assigned to treatment sequences in a balanced crossover design. Cows were housed in a tie-stall barn located at the Pennsylvania State University Dairy Production Research and Teaching Center. All cows received recombinant bST (rbST; Posilac; Elanco Animal Health, Greenfield, IN), administered every $14 \mathrm{~d}$ for the duration of the experiment. As reviewed by Bauman (1992), bST treatment has minimal effect on milk components, whereas milk yield is gradually increased, with a maximal response observed approximately $6 \mathrm{~d}$ after dosing. All animals received bST on the same day, allowing the cyclic response to be modeled as a main effect of day.

A 21-d pretrial and washout period were used to allow adaptation to MN (Table 1). Commercially sourced MN (Rumensin 90; Elanco Animal Health) was topdressed at a rate of $280 \mathrm{mg} / \mathrm{cow}$ per day (in $0.6 \mathrm{~kg}$ of cookie meal, DM basis) from d 1 to 10 and at 450 $\mathrm{mg} / \mathrm{cow}$ per day (in $1.0 \mathrm{~kg}$ of cookie meal, DM basis) from d 11 to 21 of the pretrial and washout periods. Each experimental period was divided into an MFD induction phase (14 $\mathrm{d}$ in period 1 and $10 \mathrm{~d}$ in period 2) and a recovery phase $(18 \mathrm{~d})$. In period 1 , the expected magnitude of decrease in milk fat percentage was not observed by d 7 of induction, so the induction diet was slightly modified and the induction phase extended to $14 \mathrm{~d}$. During induction, all cows were fed a lowfiber, high-unsaturated fat diet with MN (25.3\% NDF, $6.9 \% \mathrm{FA}$, and $3.24 \% \mathrm{C} 18: 2 ; 450 \mathrm{mg}$ of $\mathrm{MN} / \mathrm{cow}$ per day; Table 2; Supplemental Table S1; http://dx.doi. org/10.3168/jds.2013-7486). During recovery, cows were fed a higher-fiber and lower-unsaturated fat diet (31.2\% NDF, $4.3 \% \mathrm{FA}$, and 1.7\% C18:2). Treatments were applied during the recovery phase only, and treatments were control (no MN) or continued supplementation with $\mathrm{MN}$ topdressing (450 mg/cow per day).

Cows were fed individually once daily $(0800 \mathrm{~h})$ at $110 \%$ of expected intake and intake was observed daily. Forage and base diet DM was determined weekly for diet adjustment and DMI determination $\left(72 \mathrm{~h}\right.$ at $55^{\circ} \mathrm{C}$ in a forced-air oven). All individual feed ingredients were sampled weekly and stored at $-20^{\circ} \mathrm{C}$, thawed at room temperature, composited by period, and DM content determined as described above. Individual feeds were ground in a Wiley mill through a 1-mm screen (A. H. Thomas Co., Philadelphia, PA). Individual forages and a representative mixture of concentrate feeds were analyzed for nutrient composition by wet chemistry procedures (Cumberland Valley Analytical Services Inc., Maugansville, MD). Briefly, assays conducted were $\mathrm{DM}$ and $\mathrm{CP}$ according to AOAC International (2000); NDF and ADF according to Van Soest et al. (1991), using heat-stable amylase and sodium sulfite;

Table 1. Treatment sequences in a crossover design evaluating the effect of monensin (MN) removal on recovery from diet-induced milk fat depression (MFD)

\begin{tabular}{|c|c|c|c|c|}
\hline Sequence & Pretrial $(21 \mathrm{~d})$ & Period $1\left(14 \mathrm{~d}^{1} \rightarrow 18 \mathrm{~d}\right)$ & Washout $(21 \mathrm{~d})$ & Period $2(10 \mathrm{~d} \rightarrow 18 \mathrm{~d})$ \\
\hline 1 & MN; step-up ${ }^{2}$ & Induction $+\mathrm{MN} \rightarrow$ recovery $+\mathrm{MN}^{3}$ & MN; step-up & Induction $+\mathrm{MN} \rightarrow$ recovery $-\mathrm{MN}$ \\
\hline 2 & MN; step-up & Induction $+\mathrm{MN} \rightarrow$ recovery $-\mathrm{MN}$ & MN; step-up & Induction $+\mathrm{MN} \rightarrow$ recovery $+\mathrm{MN}$ \\
\hline
\end{tabular}


Table 2. Ingredient and chemical composition of diets

\begin{tabular}{|c|c|c|}
\hline \multirow[b]{2}{*}{ Item } & \multicolumn{2}{|c|}{$\operatorname{Diet}^{1}$} \\
\hline & Induction & Recovery \\
\hline \multicolumn{3}{|l|}{ Ingredient, $\%$ of DM } \\
\hline Corn silage $^{2}$ & 29.6 & 36.5 \\
\hline Alfalfa haylage ${ }^{3}$ & 7.1 & 17.9 \\
\hline Canola meal & 16.3 & 13.9 \\
\hline Ground corn & 22.5 & 9.9 \\
\hline Roasted soybeans & 4.0 & - \\
\hline Expeller soybean meal ${ }^{4}$ & 2.0 & 4.5 \\
\hline Cottonseed hulls & 2.6 & 2.2 \\
\hline Cookie meal $^{5}$ & 3.1 & 3.3 \\
\hline Grass hay/straw ${ }^{6}$ & 3.2 & 4.5 \\
\hline Mineral and vitamin $\operatorname{mix}^{7}$ & 3.4 & 3.3 \\
\hline Sugar cane molasses ${ }^{8}$ & 3.6 & 3.9 \\
\hline Soybean oil & 2.1 & - \\
\hline NPN supplement ${ }^{9}$ & 0.4 & 0.2 \\
\hline \multicolumn{3}{|l|}{ Nutrient, \% of DM } \\
\hline $\mathrm{CP}$ & 19.1 & 17.6 \\
\hline NDF & 25.3 & 31.2 \\
\hline $\mathrm{ADF}$ & 16.5 & 20.6 \\
\hline Starch & 30.6 & 24.6 \\
\hline FA & 6.9 & 4.3 \\
\hline C18:1n-9 & 1.45 & 0.9 \\
\hline $\mathrm{C} 18: 2 \mathrm{n}-6$ & 3.24 & 1.70 \\
\hline C18:3n-3 & 0.46 & 0.32 \\
\hline
\end{tabular}

${ }^{1}$ Induction was a low-fiber, high-unsaturated fat diet fed during the induction phase of each period (first 10 to $14 \mathrm{~d}$ of each period); recovery was a higher-fiber and lower-fat diet fed for $18 \mathrm{~d}$ during the recovery phase of each period.

${ }^{2}$ Contained $40 \%$ DM, $8 \%$ CP, 3.7\% FA, 34\% NDF, and $19.6 \%$ ADF (DM basis); fermentation time of 5 mo at the start of the experiment. ${ }^{3}$ Contained $39.4 \%$ DM, $21.4 \%$ CP, $3.1 \%$ FA, $41.9 \%$ NDF, and $36.6 \%$ ADF (DM basis).

${ }^{4}$ Mechanically extracted soybean meal (Turbomeal; J. L. Moyer and Sons Inc., Turbotville, PA).

${ }^{5}$ Contained $89.6 \%$ DM, $12.8 \%$ CP, $9.2 \%$ crude fat, $14.1 \%$ NDF, $59.8 \%$ NFC, and $4.1 \%$ ash.

${ }^{6}$ Contained $89.4 \%$ DM, $8.9 \%$ CP, $2.3 \%$ FA, $69.2 \%$ NDF, and $42.4 \%$ $\mathrm{ADF}$ (DM basis).

${ }^{7}$ Composition (DM basis): $11 \% \mathrm{CP}, 18 \% \mathrm{NDF}, 5.2 \%$ fat, $14.9 \% \mathrm{Ca}$, $0.35 \% \mathrm{P}, 4.58 \% \mathrm{Mg}, 0.41 \% \mathrm{~K}, 0.31 \% \mathrm{~S}, 357 \mathrm{mg}$ of $\mathrm{Cu} / \mathrm{kg}, 1,085 \mathrm{mg}$ of $\mathrm{Zn} / \mathrm{kg}, 181 \mathrm{mg}$ of $\mathrm{Fe} / \mathrm{kg}, 6.67 \mathrm{mg}$ of $\mathrm{Se} / \mathrm{kg}, 262,105 \mathrm{IU} / \mathrm{kg}$ of vitamin A (retinyl acetate), $65,421 \mathrm{IU} / \mathrm{kg}$ of vitamin D (activated 7-dehydrocholesterol), and 1,970 IU $/ \mathrm{kg}$ of vitamin E (DL- $\alpha$ tocopheryl acetate).

${ }^{8}$ Contained $50.2 \%$ DM, $61 \%$ invert sugar, $6.7 \%$ CP, $2.8 \%$ FA, $2.3 \%$ NDF, $1.2 \%$ ADF, and $11 \%$ ash (DM basis).

${ }^{9}$ Controlled-release urea (Optigen; Alltech Inc., Lexington, KY; $278 \%$ $\mathrm{CP}, \mathrm{DM}$ basis).

and starch according to Hall (2009). Total FA concentration and FA profile of the TMR were determined by gas chromatography after direct methylation (Sukhija and Palmquist, 1988). Monensin concentration in the topdressing was measured by HPLC with tandem mass spectrometry (Covance Inc. laboratories, Greenfield, IN).

Cows were milked twice per day at 0500 and $1700 \mathrm{~h}$ and milk yield was determined by an integrated milk meter (Afimilk; SAE Afikim, Kibbutz Afikim, Israel). Milk was sampled at both milkings every $3 \mathrm{~d}$ during recovery phases. One subsample was stored at $4^{\circ} \mathrm{C}$ with preservative (Bronolab WII; D \& F Control Systems Inc., Dublin, CA) until analyzed for fat (filter B) and protein by infrared spectroscopy [Fossomatic 4000, MilkoScan, and Fossomatic 400 (Foss Electric A/S, Hillerød, Denmark); AOAC International (2000) method 972.160 (Dairy One laboratory, Ithaca, NY)]. A second subsample was immediately spun at $3,000 \times g$ for 30 min at $4^{\circ} \mathrm{C}$ and fat cake stored at $-20^{\circ} \mathrm{C}$. Samples were thawed at room temperature in water, pooled within day by milk fat yield, and analyzed for FA composition as described by Rico and Harvatine (2013). Briefly, milk lipids were extracted with hexane-isopropanol and transmethylated in the presence of sodium methoxide. Quantification of FA methyl esters was performed by gas chromatography with a flame ionization detector and a capillary column (SP-2560; $100 \mathrm{~m} \times 0.25 \mathrm{~mm}$ i.d. with $0.2-\mu \mathrm{m}$ film thickness; Supelco Inc. Bellefonte, $\mathrm{PA})$. The initial oven temperature was $80^{\circ} \mathrm{C}$, which was increased by $2^{\circ} \mathrm{C} / \mathrm{min}$ to $190^{\circ} \mathrm{C}$ and held for $15 \mathrm{~min}$, and then increased by $8^{\circ} \mathrm{C} / \mathrm{min}$ to $215^{\circ} \mathrm{C}$ and held for 17 min. Last, when separation of trans-10 C18:1 and trans-11 C18:1 was not achieved, a second $165^{\circ} \mathrm{C}$ isothermal run was conducted to quantify these isomers. Milk FA are reported as NEFA as described by Rico and Harvatine (2013). The milk FA desaturase indexes were calculated for each sample as an estimation of the activity of the stearoyl CoA desaturase enzyme [product/(substrate + product)].

\section{Statistical Analysis}

Data were analyzed using PROC MIXED of SAS with repeated measures (version 9.3; SAS Institute Inc., Cary, NC) according to the following model: $\mathrm{Y}_{\mathrm{ijjk}} \mathrm{mn}=\mu$ $+\mathrm{S}_{\mathrm{i}}+\mathrm{P}_{\mathrm{j}}+\mathrm{C}_{\mathrm{k}}\left(\mathrm{S}_{\mathrm{i}}\right)+\mathrm{X}_{\mathrm{l}} \mathrm{T}_{\mathrm{m}}+\mathrm{D}_{\mathrm{n}}+\mathrm{T}_{\mathrm{m}} \times \mathrm{D}_{\mathrm{n}}+\mathrm{e}_{\mathrm{ijk} \mathrm{kmn}}$, where $Y_{\mathrm{ijklmn}}$ is the variable of interest, $\mu$ is the overall mean, $\mathrm{S}_{\mathrm{i}}$ is the random effect of sequence ( $\mathrm{i}=1$ to 2 ), $P_{j}$ is the random effect of period ( $j=1$ to 2$), C_{k}\left(S_{i}\right)$ is the random effect of cow nested in sequence $(\mathrm{k}=$ 1 to 16$), X_{1}$ is the fixed effect of $d 0$ of the recovery phase as a covariate, $T_{m}$ is the fixed effect of treatment $(\mathrm{m}=1$ to 2$), \mathrm{D}_{\mathrm{n}}$ is the fixed effect of time $(\mathrm{n}=1$ to 7), $T_{m} \times D_{n}$ is the interaction of treatment and time, and $e_{i j k l m n}$ is the residual error. The ARH (1) or AR(1) covariance structures were used based on model fit, time was the repeated variable, and cow by treatment was the subject. Preplanned contrasts tested the effect of MN at each time point. Significance and tendencies were declared at $P<0.05$ and $P<0.10$, respectively, for main effects and preplanned contrasts and at $P<$ 0.10 and $P<0.15$, respectively, for interactions. The denominator degrees of freedom were adjusted by the Kenward-Rogers method. 
Second, a random regression analysis was performed on milk fat and select FA concentration and yield [PROC MIXED of SAS, version 9.3 (SAS Institute Inc.)] according to the following model: $\mathrm{Y}_{\mathrm{ijklm}}=\mu+\mathrm{C}_{\mathrm{i}}+\mathrm{P}_{\mathrm{j}}$ $+T_{k}+D_{l}+D_{l}^{2}+T_{k} \times D_{l}+T_{k} \times D_{l}^{2}+e_{i j k l m}$, where $\mathrm{Y}_{\mathrm{ijklm}}$ is the variable of interest $\mu$ is the overall mean, $\mathrm{C}_{\mathrm{i}}$ is the random effect of cow ( $\mathrm{i}=1$ to 16 ), $\mathrm{P}_{\mathrm{j}}$ is the random effect of period ( $\mathrm{j}=1$ to 2 ), $\mathrm{T}_{\mathrm{k}}$ is the fixed effect of treatment ( $\mathrm{k}=1$ to 1$), \mathrm{D}_{1}$ is the linear effect of time (1 $=1$ to 7$), \mathrm{D}_{1}^{2}$ is the quadratic effect of time $(1=1$ to 7$)$, $T_{k} \times D_{1}$ is the interaction of treatment and time, $T_{k} \times$ $\mathrm{D}_{1}^{2}$ is the interaction of treatment and quadratic effect of time, and $\mathrm{e}_{\mathrm{ijk} k \mathrm{~m}}$ is the residual error. Cow was the subject, and the model included a random intercept. The denominator degrees of freedom were adjusted by the Satterthwaite method. A reduced model was used when higher-level interaction terms were not significant and did not improve model fit. The ARH (1), AR(1), or UN covariance structures were used based on model fit. Significance and tendencies were declared at $P<0.01$ and $P<0.05$, respectively, for main effects and at $P<$ 0.05 and $P<0.10$, respectively, for interactions.

Data were logarithmically transformed when appropriate, but back-transformed for reporting. For both analyses, data points with studentized residuals outside of \pm 3.0 were considered outliers and excluded from the analysis (less than 3 per response variable).

\section{RESULTS}

\section{Induction of MFD}

The induction diet reduced milk fat concentration by $23.0 \pm 2.25 \%$ (mean $\pm \mathrm{SD}$ ) by the end the MFD induc- tion phase, allowing for observation of recovery in both periods. Mean milk fat concentrations at the start and end of each MFD induction phase were 3.69 and $2.84 \%$, respectively $(\mathrm{SEM}=0.16)$. The chemical compositions of the diets were similar to expected values and $\mathrm{MN}$ concentration in the premix was $102 \%$ of the targeted dose.

\section{DMI and Milk Production and Composition}

A significant effect of time, but no effect of treatment or treatment by time interaction was observed on DMI (Table 3). Intake decreased initially and then progressively increased during recovery (Figure 1a). Milk yield decreased progressively in both treatments (time effect: $P=0.01$ ), but no effect of treatment or treatment by time interaction was detected (Table 3). A tendency was observed for lower milk yield in MN than control treatments on d $9(P<0.09$; Figure $1 \mathrm{~b})$. No treatment by time interaction effect existed on milk protein concentration and yield, which decreased progressively in both treatments (time effect: $P<0.01$; Table 3 ) and was not different between treatments at any time point (Supplemental Figure S1; http://dx.doi.org/10.3168/ jds.2013-7486).

Milk fat concentration and yield increased progressively for both treatments during recovery (time effect: $P<0.001)$. A treatment by time interaction effect was observed on milk fat concentration. Monensin decreased milk fat concentration on d 3 and 6 and tended to decrease milk fat concentration on d 9 and $15(P<$ $0.1)$; however, $\mathrm{MN}$ was not different from the control on d 18 (Figure 1c). No treatment by time interaction effect was observed on milk fat yield $(P=0.15)$,

Table 3. Effect of monensin (MN) supplementation on DMI and milk yield and composition during recovery from diet-induced milk fat depression

\begin{tabular}{|c|c|c|c|c|c|c|}
\hline \multirow[b]{2}{*}{ Item } & \multicolumn{2}{|c|}{ Treatment $^{1}$} & \multirow[b]{2}{*}{ SEM } & \multicolumn{3}{|c|}{$P$-value ${ }^{2}$} \\
\hline & Control & $\mathrm{MN}$ & & Trt & Time & Trt $\times$ time \\
\hline $\begin{array}{l}\text { DMI, } \mathrm{kg} / \mathrm{d} \\
\text { Milk yield, } \mathrm{kg} / \mathrm{d}\end{array}$ & 27.3 & 27.1 & 0.85 & 0.52 & $<0.001$ & 0.91 \\
\hline $\begin{array}{l}\text { Milk } \\
\text {. }\end{array}$ & 40.7 & 39.6 & 0.70 & 0.25 & 0.01 & 0.60 \\
\hline Fat & 1.26 & 1.17 & 0.03 & 0.02 & $<0.001$ & 0.15 \\
\hline Protein & 1.28 & 1.26 & 0.02 & 0.49 & $<0.001$ & 0.52 \\
\hline \multicolumn{7}{|l|}{ Milk composition, \% } \\
\hline Fat & 3.15 & 3.01 & 0.06 & 0.01 & $<0.001$ & 0.05 \\
\hline Protein & 3.17 & 3.18 & 0.04 & 0.67 & $<0.001$ & 0.98 \\
\hline \multicolumn{7}{|l|}{ Milk FA by source, ${ }^{3} \mathrm{~g} / \mathrm{d}$} \\
\hline$<16 \mathrm{C}$ & 287 & 275 & 12.5 & 0.23 & $<0.001$ & 0.46 \\
\hline $16 \mathrm{C}$ & 312 & 292 & 7.8 & 0.03 & $<0.001$ & 0.26 \\
\hline$>16 \mathrm{C}$ & 486 & 439 & 12.2 & 0.01 & 0.04 & 0.04 \\
\hline
\end{tabular}

${ }^{1}$ Control $=$ no $\mathrm{MN}$ during recovery; $\mathrm{MN}=\mathrm{MN}$ fed at $450 \mathrm{mg} / \mathrm{cow}$ per day during recovery.

${ }^{2}$ Trt $=$ main effect of treatment; time $=$ main effect of day of recovery; Trt $\times$ time $=$ interaction of treatment and time.

${ }^{3}$ Fatty acids $<16 \mathrm{C}$ originate from de novo synthesis in the mammary gland; FA $>16 \mathrm{C}$ originate from plasma; 16-C FA originate from both sources. 

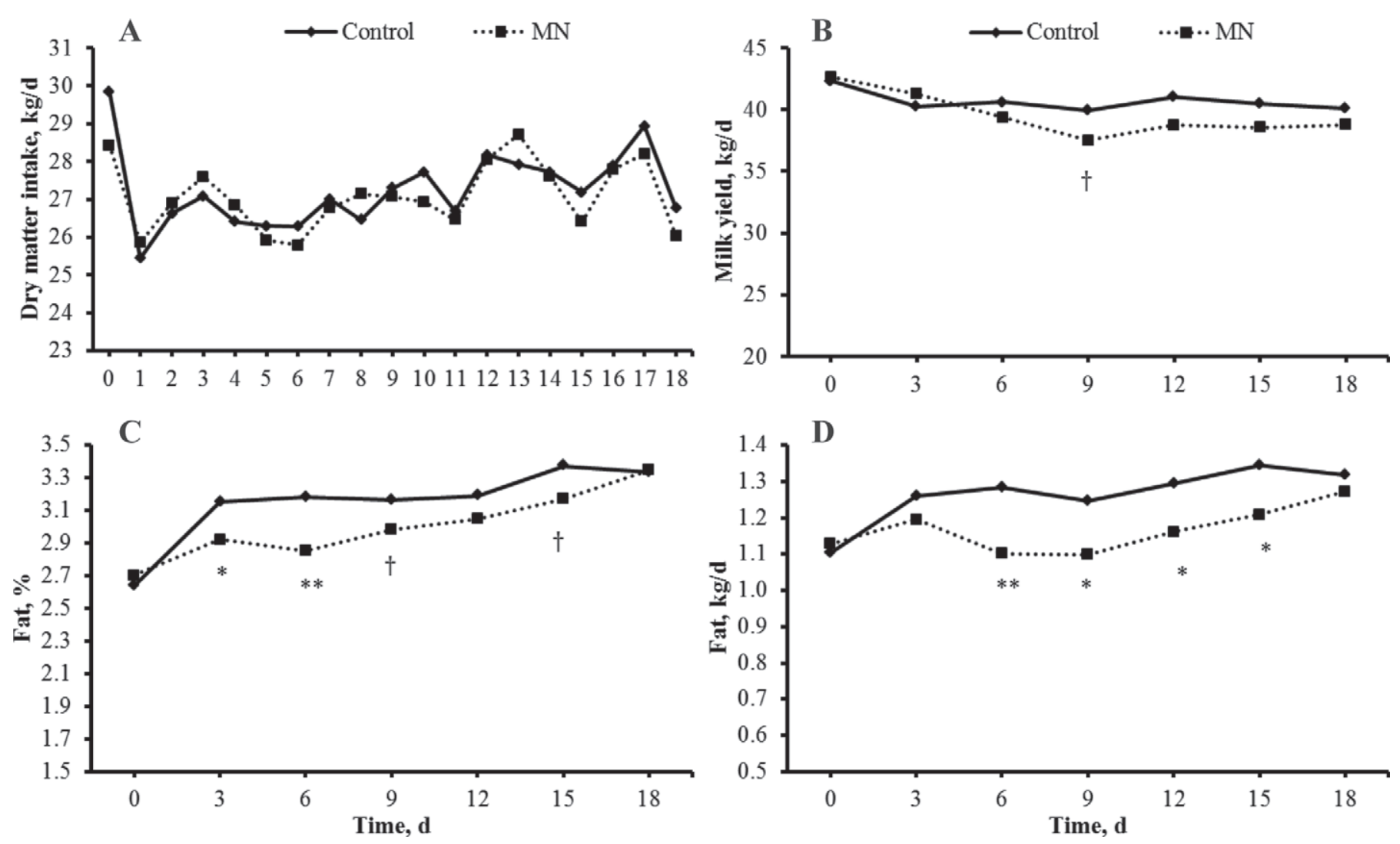

Figure 1. Effect of monensin (MN) supplementation on DMI (panel A), milk yield (panel B), and milk fat yield (panel C) and concentration (panel D) during recovery from milk fat depression (MFD). Milk fat depression was first induced by feeding a low-fiber, high-unsaturated fat diet with MN. Recovery from MFD was promoted by feeding a higher-fiber and lower-unsaturated fat diet without (control) or with continued MN supplementation for $18 \mathrm{~d}$. Preplanned contrasts tested the difference between control and $\mathrm{MN}(* * P<0.01 ; * P<0.05 ; \dagger P<0.1 ; \mathrm{SEM}=$ $0.85,0.70,0.06$, and 0.03 for panels A to $\mathrm{D}$, respectively).

but a main effect of treatment was observed, as $\mathrm{MN}$ decreased milk fat yield by $7 \%(P=0.02$; Table 3$)$. Specifically, milk fat yield was decreased by MN from d 6 to 15 ( $P<0.05$; Figure $1 \mathrm{~d})$, but it was not different from the control on d 18. By regression analysis, linear and quadratic treatment by time interaction effects were detected on both milk fat concentration and yield $(P<0.01$; Table 4$)$, as control increased rapidly and plateaued, whereas MN continued to increase during the observed period (Supplemental Figure S2; http:// dx.doi.org/10.3168/jds.2013-7486).

\section{Milk FA by Source}

An effect of time $(P<0.01)$, but no effect of treatment or treatment by time interaction was observed on milk fat concentration of FA less than $16 \mathrm{C}$ (de novo synthesized) and 16-C FA (Table 5). However, a tendency existed for a treatment by time interaction effect on the concentration of FA greater than $16 \mathrm{C}(P$ $=0.13$; preformed FA; Table 5 ). The concentration of both milk de novo and 16-C FA increased progressively in both treatments during recovery and were not different between treatments at any time point (Figures $2 \mathrm{a}$ and $2 \mathrm{c}$ ). In contrast, the concentration of preformed FA decreased progressively in both treatments, tended to be lower in the MN treatment on d $3(P<0.1)$, and was decreased by MN on d 15 and 18, respectively $(3.1 \pm 0.06 \%$; mean $\pm \mathrm{SD} ; P<0.05)$. Results of the regression analysis agreed with the above description (Supplemental Table S2 and Figure S3; http://dx.doi. org/10.3168/jds.2013-7486). Briefly, the concentration of de novo synthesized FA increased quadratically and the concentration of preformed FA decreased quadratically in both treatments $(P<0.001)$, but no treatment by time interaction effects were detected.

Yield of milk de novo FA increased progressively during recovery in both groups, but tended to be decreased by $\mathrm{MN}$ on d 6 and $9(P<0.1$; Figure $2 \mathrm{~b})$; however, no effect was observed of treatment or treatment by time interaction $(P>0.2$; Table 3$)$. The yield of $16-\mathrm{C} \mathrm{FA}$ was affected by time and treatment and was decreased by $\mathrm{MN}$ on $\mathrm{d} 6$ and $9(P<0.05)$ and tended to be lower on d $15(P=0.06$; Table 3 ; Figure $2 \mathrm{~d})$. A treatment 
Table 4. Effect of monensin (MN) supplementation on the rate of recovery of milk composition and FA profile determined by random regression

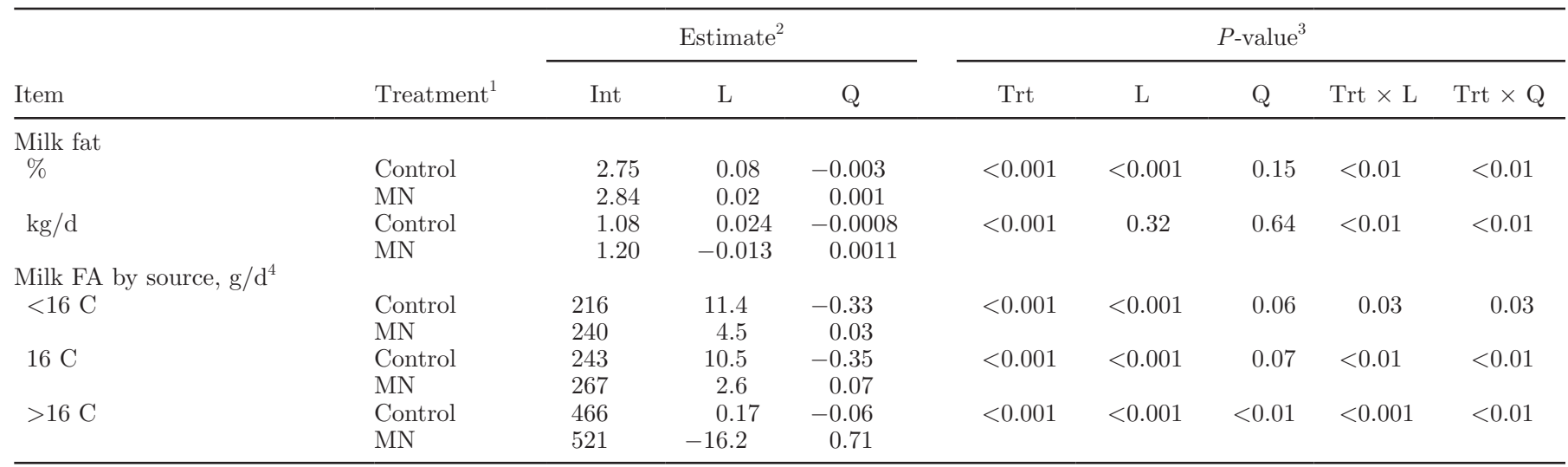

${ }^{1}$ Control = no MN during recovery; $\mathrm{MN}=\mathrm{MN}$ fed at $450 \mathrm{mg} /$ cow per day during recovery.

${ }^{2}$ Intercept (Int) and slopes of the regression terms; $\mathrm{L}=$ linear and $\mathrm{Q}=$ quadratic effects of day during recovery from milk fat depression. ${ }^{3}$ Probability for an effect of each regression term. Trt $=$ treatment effect; Trt $\times \mathrm{L}=$ interaction of treatment and the linear effect of day of recovery; Trt $\times \mathrm{Q}=$ interaction of treatment and the quadratic effect of day of recovery.

${ }^{4}$ Fatty acids $<16 \mathrm{C}$ originate from de novo synthesis in the mammary gland; FA $>16 \mathrm{C}$ originate from plasma; 16-C FA originate from both sources.

by time interaction effect was observed on the yield of milk preformed FA. The control treatment maintained a near constant yield of preformed FA, whereas the $\mathrm{MN}$ treatment reduced preformed FA progressively and decreased them by $13.9 \pm 2.0 \%$ (mean $\pm \mathrm{SD}$ ) from $\mathrm{d} 6$ to 15 (Table 3; Figure 2f). By regression analysis, the yield of FA by source followed a similar pattern and linear and quadratic interactions with treatment effects were observed on de novo, 16-C, and preformed FA $(P$ $<0.05$; Table 4; Supplemental Figure S4; http://dx.doi. org/10.3168/jds.2013-7486). Monensin decreased the linear rate of recovery of both de novo and 16-C FA yield, whereas the quadratic rate was greater than the control, thus exhibiting a progressive increase without reaching a plateau by d 18. Additionally, preformed FA yield had a greater linear rate of decrease for MN $(P$ $<0.01 ; 0.17$ and $-16.2 \mathrm{~g} / \mathrm{d}$ for control and MN treatments, respectively), whereas the quadratic rate was dramatically higher $(P<0.01)$, with MN exhibiting a progressive increase only after d 12 of recovery.

\section{Milk trans Isomers}

An effect of time $(P<0.01)$, but no effect of treatment or treatment by time interaction was observed on milk trans FA isomers (Table 4). trans-10 C18:1 and

Table 5. Effect of monensin (MN) supplementation on milk FA composition during recovery from diet-induced milk fat depression

\begin{tabular}{|c|c|c|c|c|c|c|}
\hline \multirow[b]{2}{*}{ FA, $\%$ of total FA } & \multicolumn{2}{|c|}{ Treatment $^{1}$} & \multirow[b]{2}{*}{ SEM } & \multicolumn{3}{|c|}{$P$-value ${ }^{2}$} \\
\hline & Control & MN & & Trt & Time & Trt $\times$ time \\
\hline trans-10 C18:1 & 1.39 & 1.50 & 0.21 & 0.69 & $<0.001$ & 0.13 \\
\hline trans-11 C18:1 & 1.41 & 1.55 & 0.10 & 0.26 & $<0.001$ & 0.59 \\
\hline cis-9,trans-11 CLA & 0.84 & 0.91 & 0.05 & 0.24 & $<0.001$ & 0.58 \\
\hline trans-10, cis-12 CLA & 0.010 & 0.011 & 0.001 & 0.66 & $<0.001$ & 0.77 \\
\hline $\mathrm{FA}<16 \mathrm{C}^{3}$ & 24.3 & 24.6 & 0.33 & 0.48 & $<0.001$ & 0.80 \\
\hline $16 \mathrm{C}^{3}$ & 26.4 & 26.6 & 0.36 & 0.71 & $<0.001$ & 0.89 \\
\hline $\mathrm{FA}>16 \mathrm{C}^{3}$ & 41.4 & 40.7 & 0.51 & 0.08 & $<0.001$ & 0.13 \\
\hline C14 desaturase index ${ }^{4}$ & 0.10 & 0.11 & 0.004 & 0.44 & $<0.001$ & 0.74 \\
\hline C16 desaturase index ${ }^{4}$ & 0.06 & 0.06 & 0.002 & 0.74 & $<0.001$ & 0.45 \\
\hline
\end{tabular}

${ }^{1}$ Control = no MN during recovery; $\mathrm{MN}=\mathrm{MN}$ fed at $450 \mathrm{mg} /$ cow per day during recovery.

${ }^{2}$ Trt $=$ main effect of treatment; time $=$ main effect of day of recovery; Trt $\times$ time $=$ interaction of treatment and time.

${ }^{3}$ Fatty acids $<16 \mathrm{C}$ originate from de novo synthesis in the mammary gland; FA $>16 \mathrm{C}$ originate from plasma; 16-C FA originate from both sources.

${ }^{4} \mathrm{C} 14$ desaturase index $=\mathrm{C} 14: 1 /(\mathrm{C} 14: 1+\mathrm{C} 14: 0) ; \mathrm{C} 16$ desaturase index $=\mathrm{C} 16: 1 /(\mathrm{C} 16: 1+\mathrm{C} 16: 0)$. 

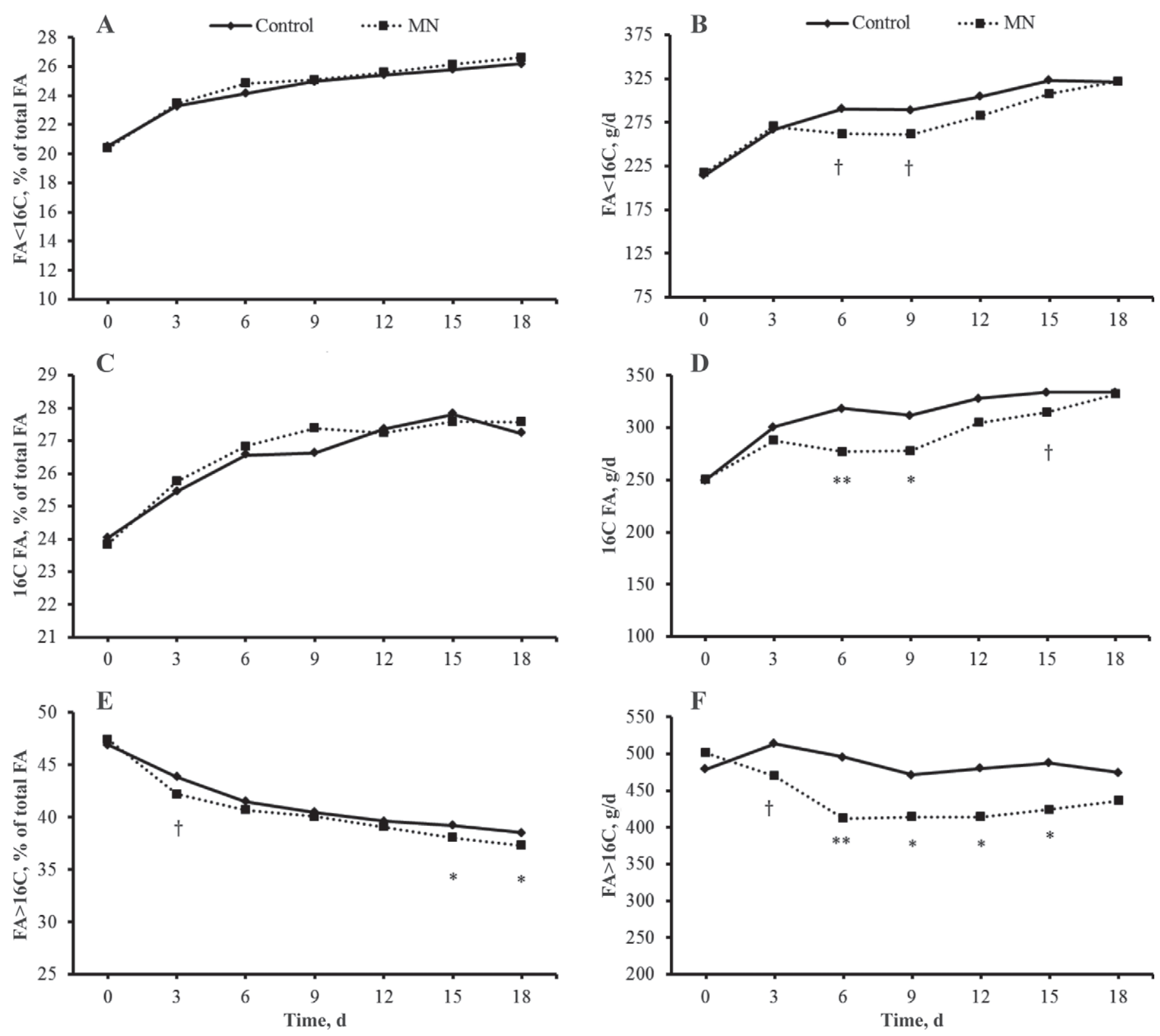

Figure 2. Effect of monensin (MN) supplementation on the concentration and yield of milk FA by source during recovery from diet-induced milk fat depression (MFD). Shown are the milk fat concentration and yield of de novo (panels A and B), 16 C (panels C and D), and preformed (panels E and F) FA. Milk fat depression was first induced by feeding a low-fiber, high-unsaturated fat diet with MN. Recovery from MFD was promoted by feeding a higher-fiber and lower-unsaturated fat diet without (control) or with continued MN supplementation for $18 \mathrm{~d}$. Preplanned contrasts tested the difference between control and $\mathrm{MN}\left({ }^{* *} P<0.01 ;{ }^{*} P<0.05 ; \dagger P<0.1 ; \mathrm{SEM}=0.33,12.5,0.36,7.8,0.51\right.$, and 12.2 for panels A to $\mathrm{F}$, respectively).

trans-10,cis-12 CLA are isomers of the alternate BH pathway. Milk trans-10 C18:1 concentration rapidly decreased in both treatments, tended to be higher in the MN treatment on d $12(P<0.1)$, and was $21 \pm 5.5 \%$ higher (mean $\pm \mathrm{SD} ; P<0.01$ ) in the $\mathrm{MN}$ than control treatment on d 15 and 18 when it reached a nadir (Figure 3a). Similarly, milk trans-10, cis-12 CLA concentration rapidly decreased and reached a nadir on d 15, but was not different between treatments at any time point (Figure 3c). trans-11 C18:1 and cis-9,trans-11 CLA are isomers of the normal BH pathway. Milk trans-11 C18:1 and cis-9,trans-11 CLA concentrations decreased progressively in both treatments through $\mathrm{d}$ 18 , but tended to be 28 and $18 \%$ higher, respectively, on d 3 in the MN treatment $(P<0.1$; Figures $3 \mathrm{~b}$ and $3 \mathrm{~d})$. By the regression analysis, both trans-10 C18:1 and trans-10,cis-12 CLA decreased quadratically ( $P$ $<0.001)$ and trans-11 C18:1 and cis-9,trans-11 CLA 

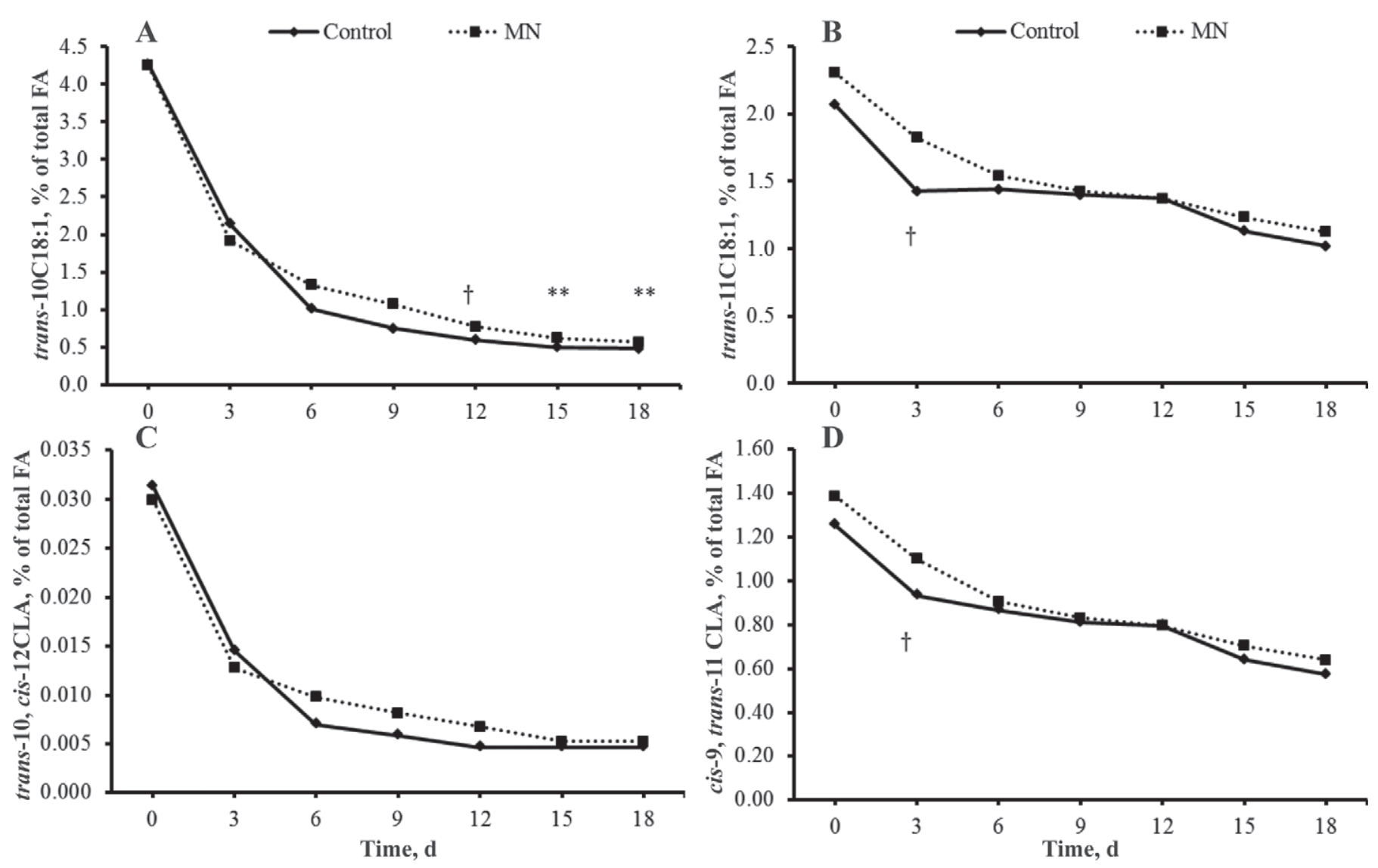

Figure 3. Effect of monensin (MN) supplementation on milk trans FA concentration during recovery from diet-induced milk fat depression (MFD). Shown are the predominant isomers of the alternate biohydrogenation pathway [trans-10 C18:1 (panel A) and trans-10,cis-12 CLA (panel C)] and the predominant isomers of the normal biohydrogenation pathway [trans-11 C18:1 (panel B) and cis-9,trans-11 CLA (panel D)]. Milk fat depression was first induced by feeding a low-fiber, high-unsaturated fat diet with MN. Recovery from MFD was promoted by feeding a higher-fiber and lower-unsaturated fat diet without (control) or with continued MN supplementation for 18 d. Preplanned contrasts tested the difference between control and $\mathrm{MN}\left({ }^{* *} P<0.01 ; \dagger P<0.1 ; \mathrm{SEM}=0.21,0.10,0.001\right.$, and 0.05 for panels A to $\mathrm{D}$, respectively).

decreased linearly, but no interactions of treatment and the linear or quadratic rate of recovery were detected (Supplemental Table S2 and Supplemental Figure S5; http://dx.doi.org/10.3168/jds.2013-7486).

\section{Milk $\Delta^{9}$-Desaturase Indices}

No treatment by time interaction effect was observed on the desaturase indexes (Table 4). The C14 and C16 desaturase indices decreased progressively, reached a nadir around d 9, and were not affected by treatment at any time point (Figure 4). The CLA index exhibited a similar time course and was not affected by treatment (data not shown).

\section{DISCUSSION}

During each experimental period, MFD was first induced by feeding a low-fiber, high-unsaturated fat diet and recovery was subsequently promoted by feeding a higher-fiber and lower-unsaturated fat diet, similar to our previous work (Rico and Harvatine, 2013). The absolute level of milk fat concentration recovery $(3.34 \%$ \pm 0.07 ) was $90 \%$ of initial values (i.e., before MFD induction). Importantly, the goal of the project was to investigate the rate of recovery, which does not require complete rescue. The length of the recovery phase was based on a previous study where recovery from dietinduced MFD was complete in $19 \mathrm{~d}$ when a high-fiber, low-unsaturated fat diet was fed (Rico and Harvatine, 2013). In addition, step-up periods of $21 \mathrm{~d}$ were used to allow adequate time for ruminal adaptation to MN.

Weimer et al. (2010) suggested that experimental designs such as Latin squares were not properly suited for microbiological studies investigating the long-term effects of MN. This was based on the observation that following MN withdrawal, some bacterial taxa and the whole bacterial community composition do not return to the same status as previous to MN supplementation (Weimer et al., 2008, 2010). Importantly, our experimental design was not investigating the steady-state 


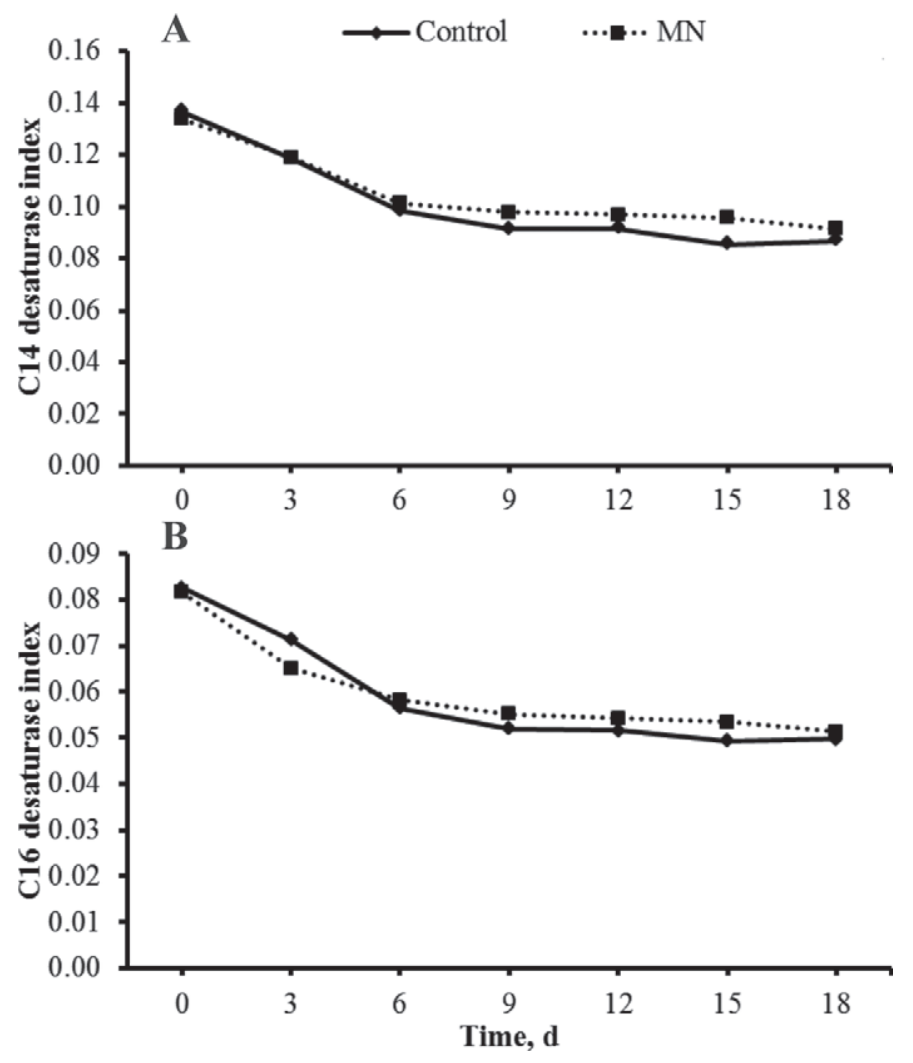

Figure 4. Effect of monensin (MN) supplementation on milk FA desaturase indexes during recovery from diet-induced milk fat depression (MFD). Representative indices shown include the C14 desaturase index (panel A) and the C16 desaturase index (panel B). Milk fat depression was first induced by feeding a low-fiber, high-unsaturated fat diet with MN. Recovery from MFD was promoted by feeding a higher-fiber and lower-unsaturated fat diet without (control) or with continued MN supplementation for $18 \mathrm{~d}$. Preplanned contrasts tested the difference between control and $\mathrm{MN}$ ( $\mathrm{SEM}=0.004$ and 0.002 for panels $\mathrm{A}$ and $\mathrm{B}$, respectively).

effect of MN, but aimed to test the effect of immediate withdrawal of MN when MFD occurs, compared with continual feeding on the rate of recovery. Therefore, the current experiment investigates the carryover effect after removal of $\mathrm{MN}$, allowing use of a replicated design.

In a recent meta-analysis of 77 studies, MN supplementation decreased DMI by $0.3 \mathrm{~kg} / \mathrm{d}$ and increased milk yield by $0.7 \mathrm{~kg} / \mathrm{d}$ and feed efficiency by $2.5 \%$ (Duffield et al., 2008b). Under the conditions of the present experiment, MN did not change DMI and milk yield, although a numerical decrease in milk yield occurred with MN. Similarly, AlZahal et al. (2008) and He et al. (2012) observed no effect of MN on DMI and milk yield when investigating the interaction of $\mathrm{MN}$ and dietary fat.

The meta-analysis by Duffield et al. (2008b) also reported that milk fat concentration decreased 0.13 percentage units and milk fat yield was unchanged during MN supplementation. In addition, milk trans FA were increased and de novo FA were decreased during MN supplementation (Duffield et al., 2008b). To our knowledge, no previous study has evaluated the effect of MN on the rate of recovery from MFD. The reduced rate of recovery of milk fat yield was predominantly explained by a lower yield of preformed FA, although the yield of 16-C FA was also reduced to a lesser extent and the yield of de novo FA tended to be decreased at some time points. During classical diet-induced MFD, the reduction in de novo FA synthesis is greater than the reduction in preformed $\mathrm{FA}$ secretion, resulting in an increased proportion of preformed FA, especially during more severe MFD [see review by Harvatine et al. (2009)].

Previous studies on the time course of recovery from diet-induced MFD have shown progressive increases in milk fat synthesis mainly related to recovery of de novo FA, but also to a smaller recovery of preformed FA secretion (Rico and Harvatine, 2013). Interestingly, in a previous experiment where MN was supplemented during recovery from diet-induced MFD, a progressive increase in milk de novo FA secretion was observed, whereas preformed FA were maintained (our unpublished data), similar to the control group in the present experiment. Although not measured in the current experiment, it is expected that $\mathrm{MN}$ feeding resulted in a more glucogenic fermentation pattern (McGuffey et al., 2001), which may have increased insulin secretion and subsequently increased adipose uptake of preformed FA and decreased FA mobilization (Duffield et al., 2008a). This may have reduced the availability of circulating FA to the mammary gland (Griinari et al., 1997; Mackle et al., 1999). A recent meta-analysis reported a negative association between milk fat yield and propionate and glucose infusions in early lactation cows, primarily caused by reductions in milk fat preformed FA (Maxin et al., 2011). Similarly to the present experiment, hyperinsulinemic-euglycemic clamp studies using post-peak cows in positive energy balance reported a similar magnitude of reduction in milk fat yield [approximately 5\% decrease (Griinari et al., 1997; Mackle et al., 1999)]. Importantly, insulin stimulation of adipose tissue metabolism is a different mechanism from classical diet-induced MFD, which is characterized by a greater reduction in de novo-synthesized FA and is explained by the BH theory [reviewed by Harvatine et al. (2009)]. Despite the decreased rate of recovery of milk fat synthesis, no difference existed between control and MN treatments by d 18 of the recovery phase. Importantly, MN supplementation did not block the recovery from MFD with adequate correction of starch, NDF, and PUFA.

The predominant $\mathrm{BH}$ pathway during normal fermentation results in formation of trans-11 C18:1 and 
cis-9,trans-11 CLA as intermediates. However, diet-induced MFD is associated with an increase in alternate $\mathrm{BH}$ isomers, including trans-10, cis-12 CLA, which is a potent inhibitor of milk fat synthesis (Baumgard et al., 2000), and trans-10 C18:1, which is highly correlated with MFD, but may not be a bioactive FA (Lock et al., 2007). In the current experiment, both trans-10 C18:1 and trans-10,cis-12 CLA decreased rapidly in both treatments during recovery from MFD, indicating little effect of $\mathrm{MN}$ on the recovery of normal $\mathrm{BH}$ pathways and capacity. This is in agreement with the similar recovery of de novo-synthesized FA, and is indicative of almost equal recovery from classical diet-induced MFD.

During recovery from diet-induced MFD, 2 distinct phases of milk trans FA have been previously observed and referred to as a biphasic response (Rico and Harvatine, 2013). Rico and Harvatine (2013) reported that isomers in the alternative BH pathway (trans-10 C18:1 and trans-10,cis-12 CLA) progressively decreased and reached near nadir concentrations by d 7 during the first phase. In agreement, during the first phase of recovery in the present experiment, $\mathrm{FA}$ in the altered $\mathrm{BH}$ pathway, including trans-10 C18:1 and trans-10,cis-12 CLA, rapidly decreased and reached almost minimal levels by $\mathrm{d} 6$. During the second phase of the biphasic response, a brief and slight elevation of FA in the normal BH pathway, including trans-11 C18:1 and cis9,trans-11 CLA, was previously observed around d 12 and 15 (Rico and Harvatine, 2013). However, FA in the normal pathway were not elevated above baseline in the secondary phase in the current experiment, in agreement with other experiments investigating recovery in MN-supplemented diets (our unpublished data). This discrepancy in the second phase with MN supplementation suggests an effect of MN during the later stages of recovery of normal $\mathrm{BH}$ or additional experiment-specific interactions (Fellner et al., 1997; Weimer et al., 2010).

A meta-analysis by Duffield et al. (2008b) reported that MN decreased milk C18:0 by $7.8 \%$ and increased trans $\mathrm{C} 18: 1 \mathrm{FA}$ and CLA by $22 \%$, indicating reduced ruminal $\mathrm{BH}$. However, care is needed in the interpretation of milk C18:0 concentration, as C18:0 is desaturated at a high rate to cis-9 $\mathrm{C} 18: 1$ in the mammary gland. In the present experiment, no effect was detected of MN on milk concentration of C18:0, and cis-9 C18:1 was only slightly reduced on d $3(P<0.05$; data not shown), whereas trans-11 C18:1 and cis-9,trans-11 CLA tended to increase on d 3 of recovery. Ruminal bacteria that carry out $\mathrm{BH}$ are classically classified into groups A and B (Harfoot and Hazlewood, 1997). Group A bacteria can hydrogenate linoleic acid (cis-9,cis-12 18:2) into trans-11 C18:1, whereas group B bacteria (gram positive) form C18:0 from C18:1 FA, such as trans-11 C18:1. The observed tendency for higher trans-11 C18:1 and cis-9,trans-11 CLA on d 3 of recovery may be the result of ruminal accumulation of trans-11 C18:1 by inhibition of gram-positive bacteria (Russell and Houlihan, 2003) and subsequent endogenous desaturation into cis-9,trans-11 CLA by stearoyl-CoA desaturase (Griinari et al., 2000). In agreement with previous reports (Rico and Harvatine, 2013; our unpublished data), the desaturase indices decreased progressively during recovery from MFD, and the lack of treatment effect suggests little difference in mammary lipid metabolism.

\section{CONCLUSIONS}

The rate of recovery of milk fat synthesis was reduced by MN predominantly due to decreased preformed FA incorporation into milk fat. However, the reestablishment of normal rumen $\mathrm{BH}$ occurred rapidly and de novo milk fat synthesis increased almost equally with continued MN supplementation. Importantly, milk fat yield recovered to the same extent in both groups by the end of the 18-d recovery period. Therefore, MN supplementation did not block the recovery from dietinduced MFD when dietary starch, NDF, and PUFA concentrations were corrected.

\section{ACKNOWLEDGMENTS}

Gratitude is expressed to Y. Ying, M. Niu, A. R. Clarke, E. Wambaugh, and H. Stultz (all from Penn State University, University Park) for technical assistance and to all personnel at the Pennsylvania State University Dairy Cattle Research and Education Center for feeding and continuous care of animals. This project was supported by Elanco Animal Health Inc. (Greenfield, IN) and thoughtful discussion from the Elanco dairy technical service team was appreciated.

\section{REFERENCES}

AlZahal, O., N. E. Odongo, T. Mutsvangwa, M. M. Or-Rashid, T. F. Duffield, R. Bagg, P. Dick, G. Vessie, and B. W. McBride. 2008. Effects of monensin and dietary soybean oil on milk fat percentage and milk fatty acid profile in lactating dairy cows. J. Dairy Sci. 91:1166-1174.

AOAC International. 2000. Official Methods of Analysis. 17th ed. AOAC International, Gaithersburg, MD.

Bauman, D. E. 1992. Bovine somatotropin: Review of an emerging animal technology. J. Dairy Sci. 75:3432-3451.

Bauman, D. E., and J. M. Griinari. 2001. Regulation and nutritional manipulation of milk fat: Low-fat milk syndrome. Livest. Prod. Sci. 70:15-29.

Baumgard, L. H., B. A. Corl, D. A. Dwyer, A. Saebø, and D. E. Bauman. 2000. Identification of the conjugated linoleic acid isomer that inhibits milk fat synthesis. Am. J. Physiol. Regul. Integr. Comp. Physiol. 278:R179-R184.

Duffield, T. F., K. E. Leslie, D. Sandals, K. Lissemore, B. W. McBride, J. H. Lumsden, P. Dick, and R. Bagg. 1999. Effect of prepartum 
administration of monensin in a controlled-release capsule on milk production and milk components in early lactation. J. Dairy Sci. $82: 272-279$.

Duffield, T. F., A. R. Rabiee, and I. J. Lean. 2008a. A meta-analysis of the impact of monensin in lactating dairy cattle. Part 1. Metabolic effects. J. Dairy Sci. 91:1334-1346.

Duffield, T. F., A. R. Rabiee, and I. J. Lean. 2008b. A meta-analysis of the impact of monensin in lactating dairy cattle. Part 2. Production effects. J. Dairy Sci. 91:1347-1360.

Fellner, V., F. D. Sauer, and J. K. Kramer. 1997. Effect of nigericin, monensin, and tetronasin on biohydrogenation in continuous flowthrough ruminal fermenters. J. Dairy Sci. 80:921-928.

Griinari, J. M., B. A. Corl, S. H. Lacy, P. Y. Chouinard, K. V. Nurmela, and D. E. Bauman. 2000. Conjugated linoleic acid is synthesized endogenously in lactating dairy cows by $\Delta^{9}$-desaturase. J. Nutr. 130:2285-2291.

Griinari, J. M., M. A. McGuire, D. A. Dwyer, D. E. Bauman, and D L. Palmquist. 1997. Role of insulin in the regulation of milk fat synthesis in dairy cows. J. Dairy Sci. 80:1076-1084.

Hall, M. B. 2009. Determination of starch, including maltooligosaccharides, in animal feeds: Comparison of methods and a method recommended for AOAC collaborative study. J. AOAC Int. 92:42-49.

Harfoot, C. G., and G. P. Hazlewood. 1997. Lipid metabolism in the rumen. Pages 382-426 in The Rumen Microbial Ecosystem. 2nd ed. P. N. Hobson and C. S. Stewart, ed. Chapman and Hall, London, UK.

Harvatine, K. J., Y. R. Boisclair, and D. E. Bauman. 2009. Recent advances in the regulation of milk fat synthesis. Animal 3:40-54.

He, M., K. L. Perfield, H. B. Green, and L. E. Armentano. 2012. Effect of dietary fat blend enriched in oleic or linoleic acid and monensin supplementation on dairy cattle performance, milk fatty acid profiles, and milk fat depression. J. Dairy Sci. 95:1447-1461.

Ipharraguerre, I. R., and J. H. Clark. 2003. Usefulness of ionophores for lactating dairy cows: A review. Anim. Feed Sci. Technol. 106:39-57.

Jenkins, T. C., V. Fellner, and R. K. McGuffey. 2003. Monensin by fat interactions on trans fatty acids in cultures of mixed ruminal microorganisms grown in continuous fermentors fed corn or barley. J. Dairy Sci. 86:324-330.

Lean, I. J., M. Curtis, R. Dyson, and B. Lowe. 1994. Effects of sodium monensin on reproductive performance of dairy cattle. I. Effects on conception rates, calving-to-conception intervals, calving-to-heat and milk production in dairy cows. Aust. Vet. J. 71:273-277.
Lock, A. L., C. Tyburczy, D. A. Dwyer, K. J. Harvatine, F. Destaillats, Z. Mouloungui, L. Candy, and D. E. Bauman. 2007. Trans-10 octadecenoic acid does not reduce milk fat synthesis in dairy cows. J. Nutr. 137:71-76.

Mackle, T. R., D. A. Dwyer, K. L. Ingvartsen, P. Y. Chouinard, J. M. Lynch, D. M. Barbano, and D. E. Bauman. 1999. Effects of insulin and amino acids on milk protein concentration and yield from dairy cows. J. Dairy Sci. 82:1512-1524.

Maxin, G., H. Rulquin, and F. Glasser. 2011. Response of milk fat concentration and yield to nutrient supply in dairy cows. Animal 5:1299-1310.

McGuffey, R. K., L. F. Richardson, and J. I. D. Wilkinson. 2001. Ionophores for dairy cattle: Current status and future outlook. J. Dairy Sci. 84(E. Suppl.):E194-E203.

Odongo, N. E., R. Bagg, G. Vessie, P. Dick, M. M. Or-Rashid, S. E. Hook, J. T. Gray, E. Kebreab, J. France, and B. W. McBride. 2007. Long-term effects of feeding monensin on methane production in lactating dairy cows. J. Dairy Sci. 90:1781-1788.

Phipps, R. H., J. I. Wilkinson, L. J. Jonker, M. Tarrant, A. K. Jones, and A. Hodge. 2000. Effect of monensin on milk production of Holstein-Friesian dairy cows. J. Dairy Sci. 83:2789-2794.

Rico, D. E., and K. J. Harvatine. 2013. Induction of and recovery from milk fat depression occurs progressively in dairy cows switched between diets that differ in fiber and oil concentration. J. Dairy Sci. 96:6621-6630

Russell, J. B., and A. J. Houlihan. 2003. Ionophore resistance of ruminal bacteria and its potential impact on human health. FEMS Microbiol. Rev. 27:65-74.

Russell, J. B., and H. J. Strobel. 1989. Effect of ionophores on ruminal fermentation. Appl. Environ. Microbiol. 55:1-6.

Sukhija, P. S., and D. L. Palmquist. 1988. Rapid method for determination of total fatty acid content and composition of feedstuffs and feces. J. Agric. Food Chem. 36:1202-1206.

Van Soest, P. J., J. B. Robertson, and B. A. Lewis. 1991. Methods for dietary fiber, neutral detergent fiber, and nonstarch polysaccharides in relation to animal nutrition. J. Dairy Sci. 74:3583-3597.

Weimer, P. J., D. M. Stevenson, and D. R. Mertens. 2010. Shifts in bacterial community composition in the rumen of lactating dairy cows under milk fat-depressing conditions. J. Dairy Sci. 93:265278.

Weimer, P. J., D. M. Stevenson, D. R. Mertens, and E. E. Thomas. 2008. Effect of monensin feeding and withdrawal on populations of individual bacterial species in the rumen of lactating dairy cows fed high-starch rations. Appl. Microbiol. Biotechnol. 80:135-145. 